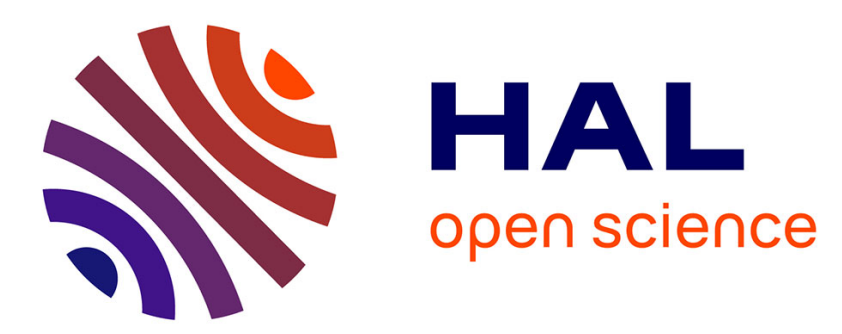

\title{
Pollutant lead reveals the pre-Hellenistic occupation and ancient growth of Alexandria, Egypt
}

Alain Veron, A. Véron, J. Goiran, C. Morhange, N. Marriner, J. Empereur

\section{To cite this version:}

Alain Veron, A. Véron, J. Goiran, C. Morhange, N. Marriner, et al.. Pollutant lead reveals the preHellenistic occupation and ancient growth of Alexandria, Egypt. Geophysical Research Letters, 2006, 33 (6), 10.1029/2006GL025824 . hal-02116119

\section{HAL Id: hal-02116119 \\ https://hal.science/hal-02116119}

Submitted on 3 May 2021

HAL is a multi-disciplinary open access archive for the deposit and dissemination of scientific research documents, whether they are published or not. The documents may come from teaching and research institutions in France or abroad, or from public or private research centers.
L'archive ouverte pluridisciplinaire HAL, est destinée au dépôt et à la diffusion de documents scientifiques de niveau recherche, publiés ou non, émanant des établissements d'enseignement et de recherche français ou étrangers, des laboratoires publics ou privés. 


\title{
Pollutant lead reveals the pre-Hellenistic occupation and ancient growth of Alexandria, Egypt
}

\author{
A. Véron, ${ }^{1}$ J. P. Goiran, ${ }^{2}$ C. Morhange, ${ }^{3}$ N. Marriner, ${ }^{3}$ and J. Y. Empereur ${ }^{4}$ \\ Received 24 January 2006; revised 10 February 2006; accepted 14 February 2006; published 30 March 2006.
}

[1] It is generally accepted that Alexandria ad Aegyptum was founded ex nihilo in $331 \mathrm{BC}$ by Alexander the Great, rapidly growing into one of antiquity's most opulent economic and intellectual centers. However, ancient texts by Strabo (17.1.6) and Pliny ( $\mathrm{NH}$ 5.11.62) suggest the existence of a pre-Hellenistic settlement named Rhakotis. This literary evidence has fuelled contentious scholarly debate for decades. Here we present new geochemical data from Alexandria's ancient bay sediments, elucidating unequivocal proof for pollutant lead $(\mathrm{Pb})$ input into the harbor during the Egyptian Old Kingdom (2686-2181 BC). A second contamination peak is detected during the Iron Age (1000-800 BC), at the end of the prosperous Ramesses reigns. These findings evidence thriving pre-Hellenistic settlements in Alexandria. During the Greek and Roman periods, we expound the largest $\mathrm{Pb}$ pollution ever encountered in ancient city sediments with $\mathrm{Pb}$ levels twice as high as those measured in contemporary industrialized estuaries. Citation: Véron, A., J. P. Goiran, C. Morhange, N. Marriner, and J. Y. Empereur (2006), Pollutant lead reveals the pre-Hellenistic occupation and ancient growth of Alexandria, Egypt, Geophys. Res. Lett., 33, L06409, doi:10.1029/ 2006GL025824.

[2] Alexandria, on the western Nile branch, is named after Alexander the Great who ordered its construction in 331 BC. In antiquity, the city flourished and its population is believed to have reached a few hundred thousand during the Roman apogee [Empereur, 1998; Yoyotte et al., 1998]. The existence of a pre-Hellenistic settlement, named Rhakotis, has never been unequivocally reconciled and debate continues to rage in the literature [Chauveau, 1999; Baines, 2003]. Here we use $\mathrm{Pb}$ and its stable isotopes to geochemically infer: (1) the growth of ancient Alexandria and release of a pollutant into the harbor and (2) a significant Bronze Age geochemical imprint, inconsistent with the Alexandria ex nihilo hypothesis. $\mathrm{Pb}$ has proved to be a powerful tool in recognizing past Greek and Roman industrial activities [Bintliff et al., 1992; Pyatt et al., 2000; Aberg et al., 2001] owing to its exclusive properties. Its corrosion resistance, malleability and low melting point mean it was

\footnotetext{
${ }^{1}$ Centre Européen de Recherche et d'Enseignement de Géosciences de l'Environnement, CNRS 6635, University Paul Cézanne, Aix en Provence, France.

${ }^{2}$ Archéorient, CNRS 5133, MOM, University Lyon II, Lyon, France.

${ }^{3}$ Centre Européen de Recherche et d'Enseignement de Géosciences de l'Environnement, CNRS 6635, University Aix-Marseille I, Aix en Provence, France.

${ }^{4}$ Centre d'Etudes Alexandrines, CNRS, Alexandria, Egypt.
}

Copyright 2006 by the American Geophysical Union. 0094-8276/06/2006GL025824 extensively used in plumbing, architecture, weight and glass making, soldering, statue casting, ship building and fishing [Lucas and Harris, 1962; Nriagu, 1983]. Furthermore, its stable isotopes can be used to evidence anthropogenically dispersed pollutant $\mathrm{Pb}$ in sedimentary archives [Chow et al., 1973; Shirahata et al., 1980; $\mathrm{Ng}$ and Patterson, 1982; Renberg et al., 1994; Shotyk et al., 1998].

[3] Sediment cores were collected in Alexandria's eastern basin (core CV) and its tombolo (core CII). Detailed sedimentological descriptions are given by Goiran [2001]. Radiocarbon dates obtained from Posidonia fibers, shells fragments and Cladocora corals provide a working chronological framework. Dates were calibrated according to Stuiver and Braziunas [1993] and are presented in calendar years in Figures 1-2 and Table 1. Pb has four stable isotopes (mass $=204,206,207,208$ ) of which the last three are endmembers of the natural uranium (U)-thorium (Th) decay chains. $\mathrm{Pb}$ ores display specific isotope ratios according to the age and the initial U-Th content of their primary geological reservoirs [Doe, 1970]. These ratios are preserved during smelting of the ores, distinguishing not only the geological origin of anthropogenically dispersed $\mathrm{Pb}$ but also pollutant versus crustal-derived $\mathrm{Pb}$. Crustal sediments usually exhibit ${ }^{206} \mathrm{~Pb} /{ }^{207} \mathrm{~Pb}$ ratios higher than 1.2 , whilst geochemical investigations on marine sediments demonstrate that small variations of 0.01 can correspond to changes in $\mathrm{Pb}$ sources and/or mineralogy [Shirahata et al., 1980; Ng and Patterson, 1982]. For the Mediterranean, this tracing ability has been developed in archeology to differentiate the geographical provenance of copper $(\mathrm{Cu})$, Silver $(\mathrm{Ag})$ and $\mathrm{Pb}$ ores during antiquity [Stos-Gale et al., 1996; Yener et al., 1991; Sayre et al., 1992]. Pb concentration and corresponding isotope ratios were measured in sediments from Alexandria's ancient harbor by thermal ionization mass spectrometry on a MAT Finnigan 262 at CEREGE. Mass fractionation was corrected using a SRM981 NIST standard. Pb concentrations were determined by isotope dilution using a ${ }^{208} \mathrm{~Pb}$ isotope spike on separate aliquots. Uncertainties (including blanks and analytical errors) of $\mathrm{Pb}$ concentration and ${ }^{206} \mathrm{~Pb} /{ }^{207} \mathrm{~Pb}$ ratios were below $1 \%$ and $0.5 \%$ respectively. Crustal Enrichment Factors (EF) were calculated as the ratio of $\mathrm{Pb}$ to aluminum (Al, a major crustal component) in the sample against $\mathrm{Pb} / \mathrm{Al}$ in crustal referenced material [McLennan, 1995]. EF below 3 are consistent with natural crust-derived $\mathrm{Pb}$. Higher enrichment values invoke a different $\mathrm{Pb}$ source, namely of anthropogenic origin. Al was determined by ICP-AES Jobin Yvon at CEREGE.

[4] Core CV permits a high-resolution inquiry of anthropogenic impacts during antiquity. A low to moderate energy depositional environment is attested by decantation clays and Posidonia fibers [Goiran et al., 2000]. Around 300 BC, 

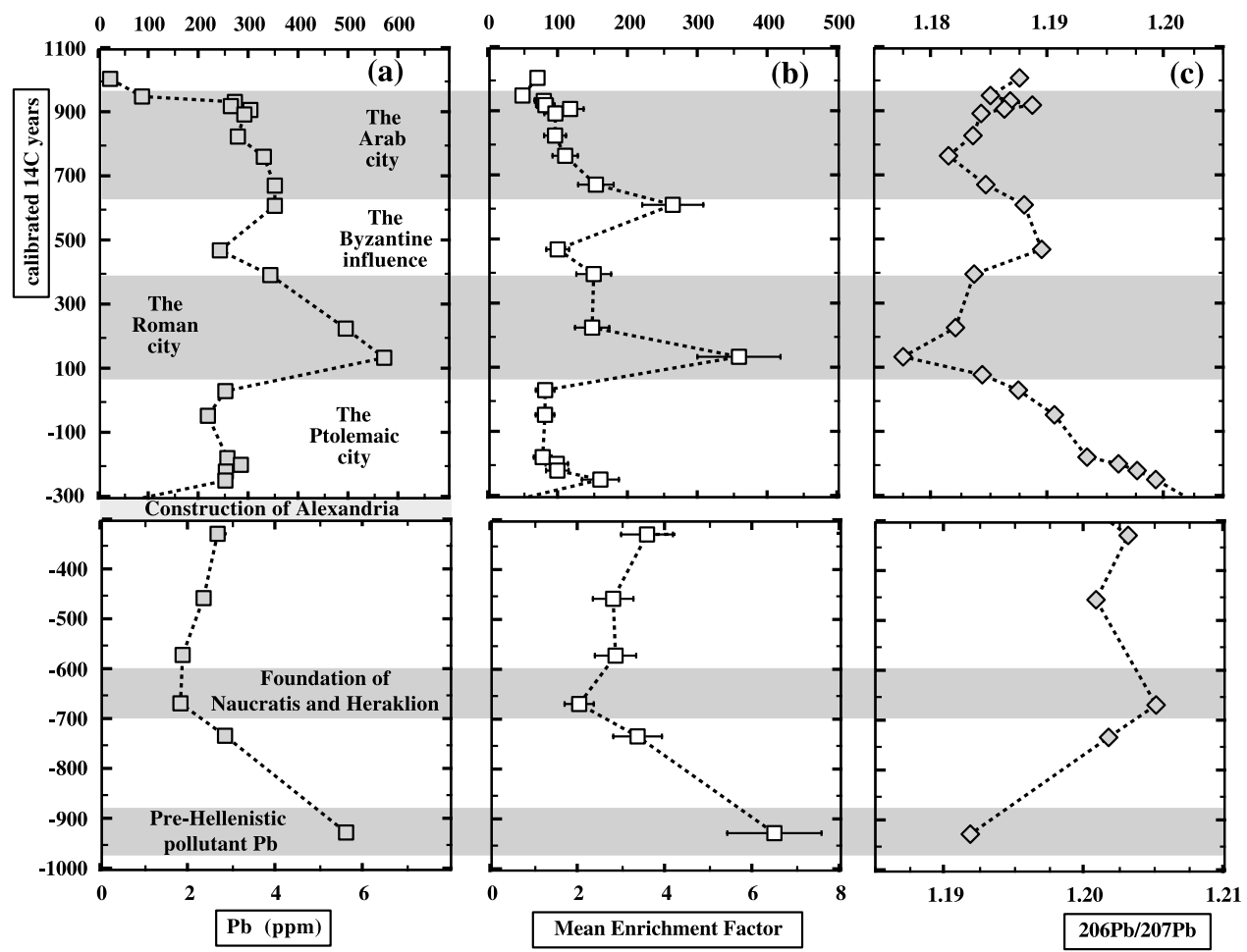

Figure 1. Changes in (a) $\mathrm{Pb}$ concentrations, (b) $\mathrm{Pb}$ enrichment factors and (c) isotope imprints in sediments from core CV.

we observe a clear change in $\mathrm{Pb}$ concentrations, shifting from 2-6 ppm to more than $200 \mathrm{ppm}$ (Figure 1a). We link this unambiguous geochemical change to the Hellenistic foundation of the city. After this period, concentration levels of $200-300 \mathrm{ppm}$ are recorded, rising rapidly to $600 \mathrm{ppm}$ during the Roman apogee (100 AD to $300 \mathrm{AD})$. Calculated EF confirm these findings and closely follow $\mathrm{Pb}$ concentration patterns, with values superior to 50 after the city's foundation (Figure 1b). These concentrations are an order of magnitude higher than those measured in sediment deposits from Sidon, the only other ancient harbor to have undergone similar geochemical investigations [Le Roux et al., 2003]. Greek and Roman Pb levels are equal to or higher than those today recorded in Alexandria's modern harbor $(90 \pm 20 \mathrm{ppm})$ [Saad et al., 2003] and present day industrialized estuaries (50 to 200ppm) [Shirahata et al., 1980; Croudace and Cundy, 1995; Feng et al., 1998; Li et al., 2000], reaching levels of toxicity similar to those defined for industrial soils. A clear isotopic contrast confirms the environmental impact of the city, with ${ }^{206} \mathrm{~Pb} /{ }^{207} \mathrm{~Pb}$ ratios shifting from crustal-derived values higher than 1.20 , prior to $300 \mathrm{BC}$, to Mediterranean $\mathrm{Pb}-\mathrm{Cu}-\mathrm{Ag}$ ore signatures during the Greek (1.187-1.199, Greek ores from Laurion, Syphnos) and Roman (1.177-1.185, Turkish ores) periods (Figure 1c) [Stos-Gale et al., 1996; Yener et al., 1991; Sayre et al., 1992; Véron and Leroux, 2004]. Isotope imprints from core CII are chronostratigraphically replicated by signatures from CV (Figure 2a). It is the first time that such high levels of environmental pollution have been recorded in an ancient marina, attesting the economic development of this metropolis with intensive commercial trade and metallurgic activities.

[5] Core CII records the accretion of the tombolo linking Pharos to the main city long before Alexander's arrival
[Goiran et al., 2000]. This result evidences the existence of a semi-enclosed and protected bay that could have been used as an anchorage haven. Pollen data (Tamarix and Cerealia) observed in this core indicate possible local human impact with a peak at the beginning of the 3rd millennium BC [Goiran, 2001]. Our Pb data sets allow three unequivocal geochemical phases to be defined for this core:

[6] - During the Predynastic period $(\sim 3800 \mathrm{BC}$ to $\sim 3000 \mathrm{BC}$ ), $\mathrm{Pb}$ concentrations and corresponding $\mathrm{EF}$ values are similar to those in pre-Hellenistic layers from core CV

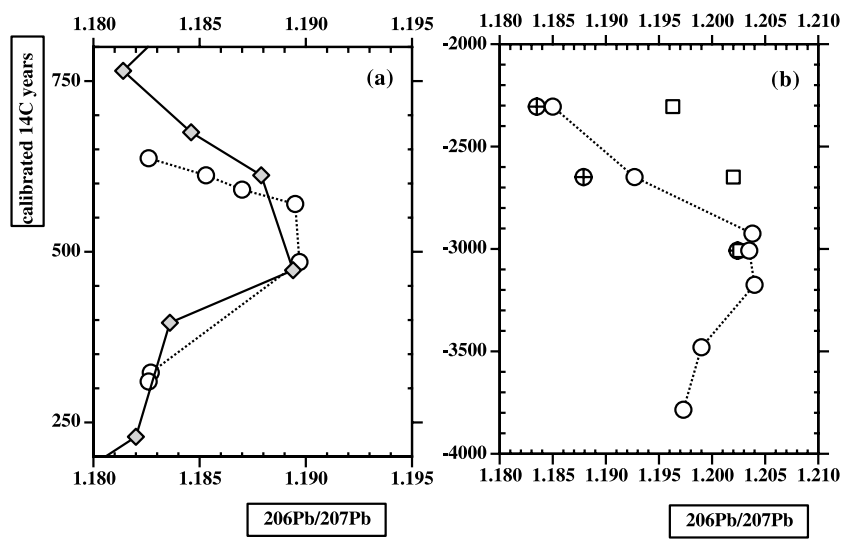

Figure 2. (a) comparison between $\mathrm{Pb}$ isotope imprints in core CV (closed lozenges) and core CII (open circles) in late Roman and Byzantine deposits; (b) Pb isotope imprints in core CII from pre-Hellenistic deposits for total $\mathrm{Pb}$ (open circles), acid leached (crossed circles) and residual (open squares) fractions. 
Table 1. Geochemical Data Set for Sediment Deposits From Core CII (Alexandria Tombolo) ${ }^{\mathrm{a}}$

\begin{tabular}{ccccccc}
\hline $\begin{array}{c}\text { Depth, } \\
\mathrm{m}\end{array}$ & $\begin{array}{c}\text { Dates } \\
\text { 14C Corr. }\end{array}$ & $\begin{array}{c}\mathrm{Pb}, \\
\mathrm{ppm}\end{array}$ & $\begin{array}{c}\mathrm{Al}, \\
\%\end{array}$ & $\mathrm{EF}$ & ${ }^{206} \mathrm{~Pb} /{ }^{207} \mathrm{~Pb}$ & ${ }^{208} \mathrm{~Pb} /{ }^{206} \mathrm{~Pb}$ \\
\hline 2.7 & $695 \pm 77 \mathrm{AD}$ & $\mathrm{nd}$ & $\mathrm{nd}$ & $\mathrm{nd}$ & $\mathrm{nd}$ & $\mathrm{nd}$ \\
3.2 & & 27.9 & nd & nd & 1.1826 & 2.0863 \\
3.9 & & 38.6 & 2.14 & 6.6 & 1.1853 & 2.0836 \\
4.2 & & 52.4 & 0.25 & 78 & 1.1870 & 2.0811 \\
4.5 & $570 \pm 96 \mathrm{AD}$ & 24.8 & 0.24 & 38 & 1.1895 & 2.0773 \\
4.8 & $485 \pm 17 \mathrm{AD}$ & 31.5 & 0.23 & 50 & 1.1897 & 2.0805 \\
5.1 & $323 \pm 36 \mathrm{AD}$ & 147 & 0.69 & 78 & 1.1827 & 2.0857 \\
5.7 & $310 \pm 53 \mathrm{AD}$ & 75.4 & 0.20 & 138 & 1.1826 & 2.0867 \\
6.2 & $2307 \pm 138 \mathrm{BC}$ & 8.66 & 0.60 & 5.3 & 1.1850 & 2.0858 \\
6.6 & & 3.33 & 1.22 & 1.0 & 1.1927 & 2.0755 \\
6.9 & $2927 \pm 88 \mathrm{BC}$ & 4.77 & $\mathrm{nd}$ & $\mathrm{nd}$ & 1.2038 & 2.0649 \\
7.2 & & 3.87 & 1.53 & 0.9 & 1.2035 & 2.0672 \\
7.7 & & 5.54 & 2.56 & 0.8 & 1.2040 & 2.0680 \\
8.4 & & 4.10 & 2.21 & 0.7 & 1.1990 & 2.0725 \\
9.3 & $3783 \pm 135 \mathrm{BC}$ & 4.16 & 1.37 & 1.1 & 1.1973 & 2.0711 \\
\hline
\end{tabular}

and represents non determined data.

(Figures $1 \mathrm{a}$ and $1 \mathrm{~b}$ and Table 1). These deposits show ${ }^{206} \mathrm{~Pb} /{ }^{207} \mathrm{~Pb}$ ratios close to 1.20 , suggesting the absence of any pollutant $\mathrm{Pb}$ (Figure $2 \mathrm{~b}$ ).

[7] - For the Middle Bronze Age, 2300 BC deposits display a significant $\mathrm{Pb}$ enrichment with $\mathrm{EF}$ of 5.3. Such enhancement is confirmed by an isotopic shift from 1.205 to 1.185 between $3000 \mathrm{BC}$ and $2300 \mathrm{BC}$ (Figure 2b). Acid leaching was performed on selected sediment samples to confirm the presence of anthropogenically-derived $\mathrm{Pb}$. Owing to its unique isotopic imprint, a light leaching $\left(\mathrm{HNO}_{3} 0.5 \mathrm{~N}\right)$ discriminates the occurrence of both residual crustal and leached pollutant $\mathrm{Pb}$. Starting in $\sim 2500 \mathrm{BC}$, sediments delineate significant differences between both fractions, with ${ }^{206} \mathrm{~Pb} /{ }^{207} \mathrm{~Pb}$ ratios close to 1.185 and higher than 1.195 for the leached and residual components respectively (Figure 2b). Middle Bronze Age release of leached $\mathrm{Pb}$ strongly suggests the onset of anthropogenic activities during the IVth dynasty. This period is characterized by a rise in the number of Nile delta settlements, as revealed by the development of durable trade between Egypt, Libya and the Sinai Peninsula [Lucas and Harris, 1962].

[8] During the Iron Age we observe a contamination peak as evidenced by EF of $6-7$ and a ${ }^{206} \mathrm{~Pb} /{ }^{207} \mathrm{~Pb}$ ratio of 1.192 (Figure 1). Such geochemical evidence for preHellenistic occupation of Alexandria is consistent with the prosperous Rameses reigns of the XIXth and XXth dynasties. At this time, the site lay within an administrative area protected by a series of fortresses constructed under Rameses II [Brinton, 1942; Baines and Malek, 2000]. It is posited that this settlement was named Raqote meaning "naval construction yard" [Depauw, 2000]. This revival at the end of the New Kingdom is followed by non contaminated overlying deposits. We postulate that the absence of any significant pollutant $\mathrm{Pb}$ between $800 \mathrm{BC}$ and Alexander's arrival resulted from decline of the Egyptian empire during the Nubian, Assyrian and Persian invasions [Butzer, 1976].

[9] Previous findings allow the origin of this pollution to be reconciled (i.e., regional versus local). Geochemical investigations clearly demonstrate the large contribution of the Nile river to sediments accumulated in the Levantine basin [Krom et al., 1999]. Meanwhile, exhaustive metal analyses of Holocene sediments deposited in the Nile delta does not evidence any noticeable $\mathrm{Pb}$ enrichment (as defined by crustal enrichment factors based on $\mathrm{Al}$ ) [Siegel et al., 1995]. Furthermore, the counter-clockwise Levantine gyre disperses Nile derived particles eastward, which prevent Nile material from reaching Alexandria bay. In addition, Alexandria bay sediments from core $\mathrm{V}$ do not record any immediate $\mathrm{Pb}$ enrichment following the foundation of close by trade cities (between 700 and 600BC), namely Naucratis, Menouthis and Heraklion [Stanley et al., 2001]. These data all corroborate a local, in situ, provenance for pollutant $\mathrm{Pb}$ encountered in ancient Alexandrian sediments.

[10] Our data are not consistent with the foundation of Alexandria ex nihilo. Pre-Hellenistic $\mathrm{Pb}$ imprints suggest the existence of an in situ Bronze Age settlement as early as the IVth dynasty. It would indeed be paradoxical to assume that such a locally unique and geologically endowed site an island breakwater sheltering a large marine bay on the extreme margin of the Nile delta - did not attract anterior societies. After an early $\sim 1000$ to $800 \mathrm{BC}$ revival, relative decline of this settlement is recorded through to the 4 th century $\mathrm{BC}$. A pronounced rise in pollutant $\mathrm{Pb}$ concentrations around $330 \mathrm{BC}$ concurs Alexander the Great's arrival, with extreme levels of pollution during the ensuing Hellenistic and Roman periods. These findings confirm pollutant $\mathrm{Pb}$ as an efficient tracer of ancient human activities and have widespread archeological implications regarding the early chapters of Alexandria's history.

[11] Acknowledgment. The authors thank the Supreme Council of Archaeology of Egypt, Lavoisier research grants, the Leverhulme Trust, the University of Alexandria, the Greco-Roman Museum of Alexandria, CEAlex UMS 1812, ACI MSH TTT 2002 and CEREGE for financial support.

\section{References}

Aberg, G., G. Charalampides, G. Fosse, and H. Hjelmseth (2001), The use of $\mathrm{Pb}$ isotopes to differentiate between contemporary and ancient sources of pollution in Greece, Atmos. Environ., 35, 4609-4615.

Baines, J. (2003), Possible implications of the Egyptian name for Alexandria, J. Roman Archeol., 16, 61-64.

Baines, J., and J. Malek (2000), Cultural Atlas of Ancient Egypt, 240 pp., Checkman Books, New York.

Bintliff, J. L., B. Davies, C. Gaffney, A. Snodgrass, and A. Water (1992), Trace metal accumulations in soils on and around ancient settlements in Greece, in Geoprospection in the Archaeological Landscape, edited by P. Spoerry, pp. 9-24, D. Brown, Bloomington, In.

Brinton, J. Y. (1942), Some recent discoveries at El-Alamein, Bull. Soc. Archeol. Alexandrie, 11, 78-81.

Butzer, K. W. (1976), Early Hydraulic Civilization in Egypt: A Study in Cultural Ecology, 134 pp., Univ. of Chicago Press, Chicago, Ill.

Chauveau, M. (1999), Alexandrie Rhakôtis: Le point de vue des Egyptiens, in Alexandrie, Une Mégapole Cosmopolite, edited by J. Leclant, pp. 1-10, Acado des Inscriptions et Belles Lett., Paris. Chow, T. J., K. W. Bruland, K. Berthine, A. Soutar, M. Koide, and E. D. Goldberg (1973), Records in southern California coastal sediments, Science, 181, 551-552.

Croudace, I. W., and A. B. Cundy (1995), A record of heavy metal pollution in recent sediments from Southampton Water, southern England: A geochemical and isotopic study, Environ. Sci. Technol., 29, 1288-1296.

Depauw, M. (2000), Alexandria, the building yard, Chron. Egypte, 75, $64-65$.

Doe, R. B. (1970), Lead Isotopes, 137 pp., Springer, New York.

Empereur, J. Y. (1998), Alexandrie Redécouverte, 253 pp., Fayard/Stock, Paris.

Feng, H., J. K. Cochran, H. Lwiza, B. J. Brownawell, and D. J. Hirschberg (1998), Distribution of heavy metal and PCB contaminants in the sediments of an urban estuary: The Hudson River, Mar. Environ. Res., 45, $69-88$. 
Goiran, J. P. (2001), Recherches Géomorphologiques dans la region littorale d'Alexandrie en Egypte, Ph.D. thesis, 262 pp., Univ. of Provence, Marseille, France.

Goiran, J. P., C. Morhange, M. Bourcier, P. Carbonel, and C. Morigi (2000), Evolution des rivages d'Alexandrie à l'Holocène récent, marge occidentale du delta du Nil, Egypte, Méditerranée, 1.2, 83-90.

Krom, M. D., R. A. Cliff, L. M. Eijsink, B. Herut, and R. Chester (1999), The characterisation of Saharan dusts and Nile particulate matter in surface sediments from the Levantine basin using $\mathrm{Sr}$ isotopes, Mar. Geol., 155, 319-330.

Le Roux, G., A. Véron, and C. Morhange (2003), Geochemical evidences of early anthropogenic activity in harbour sediments from Sidon, Archeol. Hist. Lebanon, 18, 115-119.

Li, X., O. W. H. Wai, Y. S. Li, B. J. Coles, M. H. Ramsey, and I. Thornton (2000), Heavy metal distribution in sediment profiles of the Pearl River estuary, south China, Appl. Geochem., 15, 567-581.

Lucas, A., and M. A. Harris (1962), Ancient Egyptian Materials and Industries, 523 pp., Edward Arnold, London.

McLennan, S. M. (1995), Sediments and soils: Chemistry and abundances, in A Handbook of Physical Constants: Rock Physics and Phase Relations, AGU Ref. Shelf Ser., vol. 3, edited by T. J. Ahrens, pp. 8-19, AGU, Washington, D. C.

$\mathrm{Ng}$, A., and C. C. Patterson (1982), Changes of lead and barium with time in California off-shore basin sediments, Geochim. Cosmochim. Acta, 46, $2307-2321$

Nriagu, J. O. (1983), Lead and Lead Poisoning in Antiquity, 436 pp., John Wiley, Hoboken, N. J.

Pyatt, F. B., G. Gilmore, J. P. Grattan, C. O. Hunt, and S. McLaren (2000), An imperial legacy? An exploration of the environmental impact of ancient metal mining and smelting in southern Jordan, J. Archeol. Sci., 27, 771-778.

Renberg, I., M. W. Persson, and O. Emteryd (1994), Pre-industrial atmospheric lead contamination detected in Swedish lake sediments, Nature, 368, 323-326.

Saad, M. A. H., A. I. Beltagy, and W. M. Mahmoud (2003), Total dissolved and particulate lead in the Western Harbor of Alexandria, a Mediterranean basin under stress, Mar. Pollut. Bull., 47, 52-58.

Sayre, E. V., K. A. Yener, E. C. Joel, and I. L. Barnes (1992), Statistical evaluation of the presently accumulated lead isotpe data from Anatolia and surrounding regions, Archaeometry, 34, 73-105.
Shirahata, H., R. W. Elias, and C. C. Patterson (1980), Chronological variations in concentrations and isotopic compositions on anthropogenic atmospheric lead in sediments of a remote subalpine pond, Geochim. Cosmochim. Acta, 44, 149-162.

Shotyk, W., et al. (1998), History of atmospheric lead deposition since $12,37014 \mathrm{C}$ yr BP from a peat bog, Jura Mountains, Switzerland, Science, 281, 1635-1640.

Siegel, F. R., N. Gupta, B. Shergill, D. J. Stanley, and C. Gerber (1995), Geochemistry of Holocene sediments from the Nile delta, J. Coastal Res., $11,415-431$.

Stanley, J. D., F. Goddio, and G. Schnepp (2001), Nile flooding sank two ancient cities, Nature, 412, 293-294.

Stos-Gale, Z. A., N. H. Gale, and N. Annetts (1996), Lead isotope data from the isotrace laboratory, Oxford: Archaeometry data base 3, ores from the Aegean, part 1, Archaeometry, 38, 381-390.

Stuiver, M., and T. F. Braziunas (1993), Modeling atmospheric ${ }^{14} \mathrm{C}$ influences and ${ }^{14} \mathrm{C}$ ages of marine samples to $10,000 \mathrm{BC}$, Radiocarbon, 35, $137-189$.

Véron, A., and G. Leroux (2004), Provenance of silver artefacts from burial 27 at Sidon, Archeol. Hist. Lebanon, 20, 34-38.

Yener, K., E. Sayre, E. Joel, H. Osbal, I. Barnes, and R. Brill (1991), Stable lead isotpe studies of Central Taurus ore sources and related artifacts from eastern Mediterranean chalcolithic and bronze age sites, J. Archeol. Sci., $18,541-577$

Yoyotte, J., P. Charvet, and S. Gompertz (1998), Strabon: Le Voyage en Egypte, un Regard Romain, 313 pp., Nil, Paris.

J. Y. Empereur, CEAlex CNRS 1812, 50 rue Soliman Yousri, 21131, Alexandria, Egypt. (jye@cea.com.eg)

J. P. Goiran, Archéorient CNRS 5133, MOM,Université Lyon II, 7 rue Raulin, F-69365 Lyon cedex 07, France. (jean-philippe.goiran@ mom.fr)

N. Marriner and C. Morhange, CEREGE, University Aix-Marseille I, BP 80, F-13545 Aix en Provence cedex 4, France. (nick.marriner@wanadoo. fr; morhange@cerege.fr)

A. Véron, CEREGE CNRS 6635, University Paul Cézanne, BP 80, F-13545 Aix en Provence cedex 4, France. (veron@cerege.fr) 